\title{
Kajian Hadis Dalam Ormas Islam Persatuan Islam (PERSIS)
}

\author{
Ananda Alam Mar'atus Sholikha \\ Program Studi Ilmu Hadis FUF UIN Sunan Ampel Surabaya \\ e-mail: anandaalam18@gmail.com
}

\author{
Roichatuz Zuhriyah \\ Program Studi Ilmu Hadis FUF UIN Sunan Ampel Surabaya \\ e-mail: roichatuzzuhriyah15@gmail.com
}

\author{
Abdur Rahim \\ Program Studi Ilmu Hadis FUF UIN Sunan Ampel Surabaya \\ e-mail: abdurrohim180501@gmail.com
}

\begin{abstract}
Beginning in the early 20th century when the sense of nationalism of the Indonesian nation has just grown, molding a reform movement commonly called modernism. The central theme the idea of reform in Muslim thinking on the keyword is I'adatu alIslam, one form of I'adatu al-Islam was renewed again in perspective in addressing the problems that developed with his back to the Quran and al-Hadith. namely a desire to return to the pure teachings of Islam by referring to the Qur'an and Hadith, and throw away the attitude of imitation. And one of the organizations that are reforming is the Islamic Association (PERSIS). The Islamic Association was founded in the early 1920s. Exactly on September 12, 1923 in Bandung. The idea started from an H. Zamzam He was with a close friend, $H$. Muhammad Yunus from a religious discussion activity. Persatuan Islam (PERSIS) has a distinctive orientation of thought by placing itself as a puritan Islamic Islamic understanding, as a characteristic of the study of hadith in Persian organizations or can be said to be a way of preaching in the spread of Islam that is by holding public meetings, tabligh, sermons, study groups, tadarus, the establishment of schools (pesantren), the publication of magazines and books. As for the development of these organizations in spreading Islamic da'wah, it is inseparable from the role of PERSIS figures who also produce many related works in the field of Hadith studies.
\end{abstract}

Keywords : Hadith Study; PERSIS; Puritan; the work of a figure

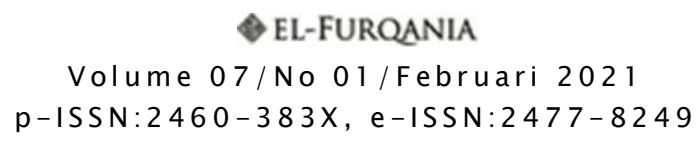




\begin{abstract}
Abstrak: Bermula pada awal abad ke 20 ketika rasa nasionalisme bangsa Indonesia baru tumbuh, menjamur sebuah gerakan pembaharuan yang biasa disebut dengan modernisme. Tema sentral ide pembaharuan pemikiran dalam Islam di atas terletak pada kata kunci I'adatu al-Islam, Salah satu wujud dari I'adatu al-lslam itu adalah memperbaharui kembali cara pandang dalam menjawab problematika yang berkembang dengan kembali kepada al-Qur'an dan al-Hadis. Yakni, sebuah keinginan untuk kembali kepada ajaran Islam yang murni dengan merujuk kepada al-Qur'an dan Hadis, serta membuang jauh-jauh sikap taklid. Dan salah satu ormas yang melakukan pembaharuan adalah Persatuan Islam (PERSIS). Persatuan Islam berdiri pada permulaan tahun 1920-an. Tepatnya tanggal 12 september 1923 di Bandung. Idenya bermula dari seorang $\mathrm{H}$. Zamzam Ia bersama teman dekatnya, H. Muhammad Yunus dari sebuah kegiatan diskusi keagamaan. Persatuan Islam (PERSIS) memiliki orientasi pemikiran yang khas dengan menempatkan dirinya sebagai paham keagamaan Islam bersifat puritan, adapun karakteristik kajian hadis dalam ormas Persis atau bisa dibilang cara dakwah dalam penyebaran Islam yakni dengan mengadakan pertemuan-pertemuan umum, tabligh, khutbah, kelompok studi, tadarus, pendirian sekolah-sekolah (pesantren), penerbitan majalahmajalah dan kitab-kitab. Adapun perkembangan ormas ini dalam menyebarkan dakwah Islam pun tak terlepas dari peran tokoh-tokoh PERSIS yang juga banyak menghasilkan karya-karya terkait dalam bidang kajian Hadis.
\end{abstract}

Kata Kunci: Kajian Hadis; PERSIS; Puritan; karya tokoh.

\title{
Prolog
}

Pada abad ke 20 dengan nama gerakan pembaharuan pemikiran Islam. Tema sentral ide pembaharuan pemikiran dalam Islam di atas terletak pada kata kunci I'adatu al-Islam, yakni keinginan masyarakat Islam untuk mengembalikan peran dunia Islam dalam percaturan global peradaban dunia, yang dulu pernah dilakukan Islam. Salah satu wujud dari I'adatu al-lslam itu adalah lajdid alfahm, yakni memperbaharui kembali cara pandang dalam menjawab problematika yang berkembang dengan kembali kepada al-Qur'an dan al-Hadis. Tajdid al-fahm ini dilakukan karena kemunduran dunia Islam diakibatkan penempatan qaululama abad pertengahan dijadikan rujukan utama dalam menjawab persoalan kontemporer 
sehingga yang terjadi kemudian adalah bias-bias dan kekakuan karena qaul itu sendiri muncul dan dirumuskan berdasarkan setting sosial oleh ulama ketika masih hidup. Adapun tema sentral gerakan untuk memulihkan dunia Islam adalah pemurnian akidah, ibadah dan semangat ijtihad di tengah masyarakat singkretik dan masyarakat yang berorientasi taklid. Menjamurnya gerakan pembaharuan pemikiran Islam seperti yang berkembang di dunia Islam di atas juga berkembang di Indonesia yang muncul pada awal abad ke-20, yang salah satunya adalah Persatuan Islam (PERSIS). Secara resmi Persis bersiri pada hari Rabu tanggal 1 Shafar $1342 \mathrm{H}$ bertepatan pada tanggal 12 September 192311 di Bandung oleh sekelompok orang Islam yang berminat dalam studi dan aktivitas keagamaan yang dipimpin oleh Haji Zamzam dan Haji Muhammad Yunus. Dengan demikian, sebagai organisasi formal yang berdiri secara resmi, maka Persis telah merupakan wadah organisasi dari umat Islam. Nama Persatuan Islam itu diberikan dengan maksud mengarahkan ruh ijtihad dan jihad,berusaha dengan sekuat tenaga untuk mencapai harapan dan cita-cita yang sesuai dengan kehendak organisasi yaitu; Persatuan pemikiran Islam, Persatuan rasa Islam, Persatuan usaha Islam, dan Persatuan suara Islam. Bertitik tolak dari persatuan pemikiran, rasa, usaha, dan suara Islam itu maka jam'iyah atau organisasi itu dinamakan 'Persatuan Islam' (Persis). ${ }^{1}$ Dalam artikel ini, penulis berusaha memaparkan pemikiran dan karakter dalam kajian hadis, kontribusinya ormas, tokoh-tokoh yang berpengaruh besar beserta karya-karyanya.

\section{Pemikiran dan Karakteristik Ormas Islam PERSIS}

Persatuan Islam memiliki pemikiran yang khas dengan menempatkan dirinya sebagai paham keagamaan Islam yang puritan di Indonesia. Hal ini dibuktikan dengan setiap doktrin yang diterapkan pada berbagai persoalan yang dihadapi umat Islam di Indonesia. Pedoman pokok yang dianut Persatuan Islam mengandung prinsip-prinsip ini secara konkret tertulis dalam Qanun Asasi atau Qanun Dakhili Persatuan Islam. Persatuan Islam memiliki orientasi pemikiran yang bersifat puritan, maksudnya ialah paham pemurnian Islam. Pemahaman keislaman yang bercorak puritan ini merupakan respon terhadap kecenderungan pemikiran yang dianut oleh kaum

\footnotetext{
${ }^{1}$ Dadan Wildan dkk, Anatomi Gerakan Dakwah (Bandung:2010) hal. 36.
} 
muslimin di Indonesia, yakni pemahaman keislaman yang bercorak kultural, yang lebih dikenal dengan Islam tradisionalis. Dalam pandangan Persatuan Islam, kaum muslimin Indonesia telah mempertahankan tradisi-tradisi yang diwariskan ulama terdahulu baik berupa pandangan-pandangan maupun metode berpikir para ulama klasik yang terdapat dalam kitab-kitab fiqih. ${ }^{2}$

Perdebatan secara terbuka antara Persis dengan ulama-ulama tradisional mengenai masalah-masalah ushalli (talafudz binniyah), talqin, pemindahan pahala kepada orangyang telah meninggal dunia, tahlilan setelah kematian, Shalat 'Ied di lapangan terbuka, bukan di dalam masjid, perbedaan antara hisab dan rukyat, khutbah Jum'at dengan menggunakan bahasa daerah atau bahasa Melayu (tidak menggunakan bahasa Arab) dan berbagai permasalahan keagamaan yang mendasar dalam praktik keseharian ibadat kaum muslimin.

Pada awalnya tampilnya Persis dalam upaya gerakan pemurnian ajaran Islam dilakukan dengan isu-isu kontroversial yang bersifat gebrakan (shock therapy) dalam usaha pembaruan pemikiran di kalangan umat Islam dengan pendekatan yang lebih polemik dan mengundang kontroversi waktu itu, bahkan terkesan revolusioner, membuat kedudukan dan peran Persis terasa unik. ${ }^{3}$ Oleh karenanya ketika organisasi ini baru berdiri tiga tahun, telah menimbulkan reaksi keras dari kalangan Islam tradisional yang kemudian pada tahun 1926 mendirikan organisasi Nahdhatul Ulama (kebangkitan ulama) sebagai organisasi tandingan untuk menghambat proses penyebaran paham-paham pembaruan yang dinilainya sangat membahayakan kelangsungan kehidupan tradisionalisme Islam. ${ }^{4}$

Dari segi inilah Persatuan Islam menghendaki apa yang seharusnya disakralkan dan apa yang tidak seharusnya disakralkan oleh umat Islam. Sebab, penilaian terhadap sesuatu yang bersifat sakral itu memiliki keterkaitan erat dengan kualitas ketauhidan dan bahkan berkaitan pula dengan wawasan keislaman yang dimiliki orang pada saat itu masih tergolong awam. Hal itu terbukti PERSIS

\footnotetext{
2 Artikel dalam jurnal Temali: jurnal pembangunan Sosial,Taufiq Rohman dan Beni, “Membangun Gerakan Inklusivisme Model Jamaah Persatuan Islam”, vol 1 no1(19 Januari 2020), 67.

3 Artikel dalam Pikiran Rakyat, Dedy Djamaluddin Malik, "Persis Terdesak Akhirnya Defensif', (Bandung, 1990), 8.

${ }^{4}$ Fachry Ali dan Bachtiar Effendi, Merambah Jalan Baru Islam: Rekonstruksi Pemikiran Islam Indonesia Masa Orde Baru, (Bandung: Mizan, 1986), 67.
} 
kemudian menjelma menjadi organisasi yang ekstrim dan liberal dalam melakukan penentangan terhadap tradisi-tradisi yang dianggap bagian dari ajaran agama seperti (bid'ah, khurafat, dan takhayyul), di samping Muhammadiyah dan Al-Irsyad.

Sebagai gerakan tajdid, Persis mempunyai ciri radikal apabila dibandingkan dengan organisasi lainnya. A. Hassan sebagai penggerak dan tokohnya dikenal sebagai ulama yang beraliran reformis, radikal dalam memutuskan sebuah hukum Islam, dan melaksanakannya berdasarkan al-Qur'an dan As-Sunah. ${ }^{5}$

Al-Qur'an dan al-Hadits memiliki arti yang amat penting bagi Persatuan Islam, karena kedua sumber ini mempresentasikan Islam dalam bentuknya yang murni, dan dalam bentuk itulah Islam dapat diadaptasi keberbagai kondisi dan konsep yang berlaku di dunia modern. Persatuan Islam berpandangan bahwa para sarjana tradisionalis telah mengabaikan dua sumber ini, dan secara keliru menekankan pentingnya interpretasi para fuqaha dan teolog muslim (mutakallimun). ${ }^{6}$

\section{Kontribusi Ormas dalam Kajian Hadis Indonesia}

Pada zamannya, KH. Zamzam dan A. Hassan adalah pemimpin Persis. Mereka adalah elit keagamaan persis. Walaupun dalam semangatnya persis itu membuka membuka pintu ijtihad bagi setiap muslim, anggota persis sendiri mempunyai perbedaan kapasitas dalam pengetahuan keagamaan. Maka, walaupun persis berpegang pada konsep ittiba dari pada taqlid, namun tetap saja dimungkinkan adanya elit keagamaan (religious elite) di dalam organisasi Persis. Karena posisi keagamaan itu sangatlah kuat dalam Persis, posisi ulama juga sangat berpengaruh. Titik tekan Persis pada ulama juga terefleksi dalam pandangan umum bahwa ulama-lah yang harus aktif dalam urusan politik dan bertindak sebagai pemimpin dan membimbing umat Islam. ${ }^{7}$ Sebagai elit kultural (cultural elite) yang menekankan ide-ide mereka untuk kembali kepada al-Qur'an dan Sunnah, para pemimpin Persis selalu ingin mengaplikasikannya dalam

\footnotetext{
${ }^{5}$ L. Stoddar, Dunia Baru Islam (Jakarta: Panitia Penerbit, 1996), hlm. 9

${ }^{6}$ Artikel dalam jurnal Temali: jurnal pembangunan Sosial,Taufiq Rohman dan Beni,

"Membangun Gerakan Inklusivisme..., 67.

${ }^{7}$ Federspiel, Howard M.,Persatuan Islam, Islamic Reform in Twentieth Century Indonesia, (New York: Modern Indonesia Project Southeast Asia Program, Cornell University, 1970), 183.
} 
masyarakat. Mereka dibantu oleh para anggota Persis untuk menjadi pionir aktivitas-aktivitas sosial yang mempunyai dasar dalam alQur'an dan Sunnah. Menurut Ust. Eman Sar'an, seorang aktivis Persis pada zamannya, praktek-praktek yang berdasarkan al-Qur'anSunnah seperti pelaksanaan shalat 'Id dan khutbah, akhirnya diterima oleh seluruh umat Islam, baik itu kaum pembaru maupun kaum tradisionalis, setelah menjadi kontroversial untuk jangka waktu yang cukup lama. ${ }^{8}$ Persis menekankan Islam sebagai suatu pandangan hidup (nizham, worldview): sistem sosial, politik, dan budaya. Dan Islam sejati itu adalah yang berdasarkan al-Qur'an dan Sunnah (nashnash yang utama) ${ }^{9}$. Singkatnya, ulama Persis membawa arus pembaruan ke dalam dinamika Islam Indonesia sejak awal abad ke-20. Aktivitas Persis di bawah bendera kembali kepada al-Qur'an dan as-Sunnah telah membawa perubahan-perubahan yang fundamental dalam kehidupan praktis Islam.

Pembahasan disini mengambil aspek perkembangan pengkajian Hadis, khususnya peranan yang dimainkan oleh ormas Islam terdapat perbedaan pendekatan dalam memahami Hadis oleh ormas Islam yang ada di Indonesia. Perbedaan pendekatan "AtasBawah", "Bawah-Atas" antara Muhammadiyah dan PERSIS satu pihak, NU dan al-Washliyah pada pihak yang lain terjadilah ketentuan-ketentuan hukum yang berbeda dalam masalah-masalah yang tidak prinsipil seperti qunut shubuh, doa bersama, zikir bersama, marhaban, dan tahlilan diakui dan diamalkan di kalangan NU dan alWashliyah. Sementara itu, Muhammadiyah dan PERSIS tidak mengakuinya. Akan tetapi ada kasus yang ditetapkan oleh Muhammadiyah dan al-Washliyah yang nas langsung tidak ditemukan seperti haramnya rokok, fitrah dengan beras, dan zakat profesi. Namun perbedaan pendekatan tersebut di atas akan berakibat kepada kadar kontribusi masing-masing terhadap pengkajian Hadis.

Oleh karena pendalilan itu harus berdasarkan al-Qur'an dan Hadis secara langsung oleh Muhammadiyah dan PERSIS, maka otomatis keduanya terus mengkaji dan bergelut Hadis dan tanpa Hadis mereka tidak serta merta menentukan suatu hukum. Sementara NU dan al-Washliyah walaupun tidak menemukan Hadis keduanya dapat menetapkan fatwa berdasarkan rumusan para ulama sehingga keduanya tidak terpaksa menelusuri Hadis. Jadi, Muhammadiyah dan

${ }^{8}$ Dadan Wildan, Sejarah Perjuangan Persis 1923-1983, (Bandung: Gema Syahida, 1995), 57

${ }^{9}$ Federspiel, Howard M.,Persatuan Islam...,188 
PERSIS terpaksa membongkar khazanah Hadis sehingga kontribusi mereka dalam pengembangan kajian Hadis Indonesia lebih besar daripada kontribusi ormas yang menganut mazhab. ${ }^{10}$

Tokoh-Tokoh Hadis dalam Ormas PERSIS dan Karyanya:

Seruan untuk kembali kepada al-Qur'an dan al-Sunnah merupakan seruan abadi Persis. Tetapi ketika ia dibentuk dan dioperasikan dalam gerakan, seruan itu mewujud dalam berbagai bentuk; setiap pemimpin memilih jalannya sendiri dan mempunyai aksentuasi yang berbeda. ${ }^{11}$ Aksentuasi tersebut dapat dilukiskan dengan mengikuti cerita figur-figur pemimpin Persis. Figur-figur berikut tidak seluruhnya menempati posisi Ketua Umum pada zaman mereka. Ahmad Hassan dan M. Natsir bukanlah Ketua Umum Persis. Mereka aktif selama kepemimpinan Zamzam, inisiator dan bapak pendiri Persis. Namun demikian, Isa Anshary yang aktif di Persis sejak tahun 1940-an adalah ketua umum kedua setelah Zamzam. Tidak diketahui secara jelas kapan periode kepemimpinan Zamzam berakhir. Tetapi yang jelas ketika Isa Anshary menjadi pemimpin puncak Persis. Anshary-lah orang yang mengorganisasikan kembali Persis setelah periode kevakumannya pada masa kekuasaan Jepang dan selama revolusi kemerdekaan Indonesia. Sejak saat itu yakni pada tahun 1948 sampai pada tahun 1960 beliau adalah ketua umum Persis. Pada tahun 1962 E. Abdurrahman menjadi Ketua Umum melalui sebuah referendum setelah adanya konflik internal di tubuh Persis. Beliau memimpin Persis sampai meninggal pada tahun 1983. Posisinya sebagai Ketua Umum digantikan oleh kadernya sendiri, yaitu A. Latief Muchtar yang memimpin Persis dari 1983 sampai 1997 ketika beliau meninggal. Kejadian seperti itu dilanjutkan ketika Shiddieq Amien kemudian menggantikan beliau (1997-2009) sampai wafat, dan digantikan oleh Prof. Dr. HM. Abdurrahman sehingga sekarang. ${ }^{12}$

Dengan demikian, figur-figur berikut bukanlah diseleksi karena posisi mereka di Persis, akan tetapi disebabkan karena

\footnotetext{
${ }^{10}$ Abdul Wahid Ramli, Perkembangan Kajian Hadis di Indonesia, Study Tokoh dan Ormas

Islam, Makalah Postgraduate Programs IAIN and UIN, (Makasar: 25-27 November, 2005), 18.

${ }^{11}$ A. Latief Muchtar, Gerakan Kembali ke Islam, (Bandung: Rosda, 1998), Xii

12 Wildan, Dadan, Yang Dai Yang Politikus: Hayat dan Perjuangan Lima Tokoh Persis, (Bandung: Rosda, 1997), 92, 126, 145, and 157.
} 
pengaruh dan kontribusi mereka terhadap kajian hadis seta perkembangannya.

KH. M Isa Anshary (1916-1969): Representasi Perjuangan Persatuan Islam politikus dan pejuang Indonesia. ${ }^{13}$

Tokoh ini dilahirkan di Sungai Batang Maninjau Sumatera Barat pada tanggal 1 Juli 1916. Pada tahun 1932 pergi ke Bandung, dan aktif secara resmi di Persatuan Islam sejak tahun 1935, setelah bergaul dan mengikuti pemikiran A. Hassan. Kemudian bersamasama M. Natsir, Fachruddin dan lain-lainnya aktif memajukan pendidikan Persatuan Islam. Sejak saat itu lah, ia mulai aktif menulis masalah-masalah agama dan politik. Antara tahun 1938-1941 sempat terbit dua buah buku karangannya berjudul; Islam dan Demokrasi dan Islam dan Kolektivisme. ${ }^{14}$ Sewaktu A. Hassan pindah ke Bangil, Isa tetap tinggal di Bandung dan pada masa Jepang ia bersama kawankawannya mendirikan organisasi Mubalig dan Ulama di Bandung bernama Majelis Islam. Ketika itu pula ia menjabat sekretaris MIAI Priangan. Pada masa kemerdekaan, KHM. Isa Anshary ${ }^{15}$ mencoba mengorganisasi kembali Persatuan Islam dan ia sendiri sebagai Ketua Umum-nya (1948-1961). Di samping itu, ia pun memegang tugas sebagai Ketua Umum Masyumi cabang Bandung (1950-1954), dan kemudian menjadi Anggota DPP Masyumi (1954-1960). Isa Anshary yang dikenal sebagai penulis yang tajam termasuk salah seorang perancang Qanun Asasi PERSIS yang telah diterima secara bulat oleh Muktamar V PERSIS (1953) dan disempurnakan pada Muktamar VIII PERSIS (1967). K.H.M. Isa Anshary juga Disebut sebagai tokoh representasi, karena ia mampu memerankan secara ganda dua kepentingan yang esensial: agama dan politik. sebagai Ketua Umum Persatuan Islam, yang dengan kemampuannya ia bertekad kuat untuk membenahi mutu dan kualitas Persatuan Islam sebagai organisasi sosial-keagamaan. Kecuali itu, ia juga tergolong pejuang politik (politisi) yang salah satu manifestasinya, ia sanggup menentang arus deras komunisme dengan membuat gerakan "Front Anti Komunis" yang muncul di saat situasi politik Demokrasi Terpimpin di bawah pimpinan Soekarno dan ide Nasakom-nya.

\footnotetext{
${ }^{13}$ Qanun Asasi, Persatuan Islam (Yogyakarta: PT Bentang Pustaka, 2010), 13.

${ }^{14}$ Abu Bakar, Sejarah Hidup KHA. Wahid Hasjim dan Karangan Tersiar, (Jakarta: Panitia buku peringatan alm. KHA. Wahid Hasjim, 1957) ,219-220.

${ }^{15}$ M. Isa Anshary, Mujahid Da'wah, (Bandung: CV. Diponegoro, 1984 ),311-312.
} 
Dalam sikap jihadnya, Isa Anshary menganggap perjuangan PERSIS sungguh vital dan kompleks, karena menyangkut berbagai bidang kehidupan umat.Dalam bidang pembinaan kader, Isa Anshary menekankan pentingnya sebuah madrasah, tempat membina kaderkader muda PERSIS. ${ }^{16}$ Semangatnya dalam hal pembinaan kader tidak pernah padam meskipun dia mendekam dalam tahanan rezim Orde Lama di Madiun, dikarenakan pada saat kepeminpinannya cenderung progresif dan politis yang menentang arus, sehingga ia sendiri kemudian dipenjarakan. Di sela-sela kesibukannya memegang jabatan-jabatan itu, K.H.M. Isa Anshary masih sempat menuangkan buah pikirannya melalui buku-buku. Antara lain Berikut karya tulis Isa Anshary: Islam dan Demokrasi (1938), Tuntunan Puasa (1940), Islam dan Kolektivisme (1941), Islam dan Nasionalisme (1955), Partai Komunis Indonesia (PKI), Pembela Negara Asing (1955), Manifes Perjuangan Persatuan Islam (1958), Bukan Komunisto Fobi, tapi Keyakinan Islam (1960), Umat Islam Menentukan Nasibnya (1961), Tugas dan Peranan Generasi Muda Islam dalam Pembinaan Orde Baru (1966), Falsafah Perjuangan Islam (1949).

\section{Mohammad Natsir (1908-1993): Ulama Politik Persatuan Islam}

Tokoh kelahiran Alahan Panjang, Sumatera Barat pada tanggal 17 Juli 1908 ini adalah putera dari Idris gelar Sultan Saripado, seorang guru. Tahun 1923 M. Natsir masuk HIS (setingkat SD sekarang), kemudian AMS (Algemene Middelbare School) sederajat dengan SLTA, di Bandung. Kemudian tahun 1932 memasuki kursus guru. Selama tinggal di Bandung inilah M. Natsir memulai hidupnya dalam masyarakat dan mempelajari Islam kepada A. Hassan, dan mempunyai hubungan rapat dengan tokoh-tokoh Persatuan Islam. Selain itu, ia mengikuti kelas khusus untuk anggotaanggota muda Persis yang belajar di sekolah-sekolah menengah Belanda. M. Natsir dalam Persatuan Islam berperan sebagai pembantu inti dalam majalah Pembela Islam. Selain itu, ia sebagai juru bicara Persatuan Islam dalam soal-soal kebudayaan, negara, dan masyarakat dalam kaitannya dengan Islam. Kemudian dalam posisinya sebagai tokoh Persatuan Islam, M. Natsir mampu memberikan warna politik yang khas bagi organisasi Persatuan Islam. Ia terus tampil dalam berbagai percaturan politik Islam. Gagasangagasan politiknya banyak diwarnai oleh pemikiran-pemikiran politik

${ }^{16}$ Qanun Asasi, Persatuan Islam., 15. 
religiusnya A. Hassan. Dalam Masyumi, M. Natsir telah berhasil memberi bentuk dan format politik Islam yang berdasar al-Qur'an dan as-Sunnah, yang memperjelas politik Islam itu, dan perbedaannya dengan politik kapitalis serta politik komunis. sebagai negarawan sejati, ${ }^{17}$ M. Natsir tercatat mampu menyelamatkan bangsa Indonesia dari perpecahan, dan Indonesia kembali menjadi negara kesatuan. Perjuangan ini kemudian dikenal dengan Mosi Integral M. Natsir yang disampaikan pada tanggal 3 April 1950, dan berhasil menyatukan 17 Negara Bagian. Demikian pula, melalui Masyumi, M. Natsir mampu meredam perbedaan yang amat tajam, misalnya antara Muhammadiyah dengan Nahdhatul Ulama (NU), antara Persatuan Islam dengan NU, dan lain sebagainya. Konsep toleransi (tasamuh) ini diperluas dalam tema dakwah intern umat Islam. M. Natsir mengadakan konsolidasi ke dalam tubuh umat Islam, dengan gagasan betapa pentingnya kesamaan pandangan sebagai muslim. menegaskan bahwa melawan arus pemurtadan yang dilakukan agama lain itu lebih penting dari bentuk-bentuk dakwah yang lainnya.

Dalam dunia politik, Natsir dikenal sebagai tokoh yang menghendaki Islam sebagai landasan atau ideologi negara. Dalam sebuah jurnal berjudul "Pandangan Mohammad Natsir Mengenai Islam Sebagai Ideologi Negara" yang di publikasikan Universitas Sumatera Utara (USU), disinggung mengenai hal ini. Natsir berpendapat agama harus dijadikan fondasi dalam mendirikan suatu negara. Agama, dalam konteks ini Islam, bukan semata-mata suatu sistem peribadatan antara makhluk dengan Tuhan yang Maha Esa. Islam lebih dari sebuah system peribadahan. Melainkan suatu kebudayaan atau peradaban yang lengkap dan sempurna. Dalam hal demikian, Islam menurut Natsir, dapat terjewantahkan dalam setiap ilmu kehidupan, mulai kehidupan masyarakat, ketatanegaraan, pemerintah, hingga perundang-undangan.

Adapun jabatan yang pernah didudukinya antara lain: Wakil Ketua Umum Persatuan Islam (1937), Ketua Partai Islam Indonesia (PII) cabang Bandung pada akhir masa penjajahan Belanda, Menteri Penerangan RI (1946-1949), Perdana Menteri RI (1950-1951), Ketua Umum Masyumi (1949-1958), Ketua Dewan Da'wah Islamiyah Indonesia sejak 1967 hingga akhir wafatnya (6 Pebruari 1993). Di tingkat Internasional, tercatat sebagai Wakil Presiden World Muslim

17 Dalam Suara Kampus IAIN SGD, Badri Khaeruman, "Mengenang Jasa M. Natsir", ( Bandung: edisi XV, 23 Pebruari 1993). 
Congress (Mu'tamar 'Alam Islami) dan Penasihat Umum Rabithah 'Alam Islami sejak 1967 dan Anggota Dewan Mesjid se-Dunia (Majelis A'lâ al-'Alami al-Masjî́d), sejak 1976. Jabatan lainnya yaitu anggota Dewan Pendiri The Oxford Centre for Islamic Studies yang berpusat di London, dan lain sebagainya. ${ }^{18}$ Berikut merupakan karya tulis Mohammad Natsir: al-Ahadis ad-Dha'ifahwa al-Maudhu'ah, Kitabal Taqrib wal Taisir Lima'rifah Sunan al-Basyir, Capita Salecta (1954), Artikel Qur'an en Evangelie (Qur'an dan Injil) danMuhammad als Profeet (Muhammad sebagai Nabi).

\section{Ahmad Hassan (1887-1958): Guru Persatuan Islam}

Hassan merupakan sosok ilmuwan PERSIS, dan terkenal juga sebagai seorang mujtahid. Ia dilahirkan di Singapura pada tahun 1887. Ayahnya bernama Ahmad berasal dari India, sedangkan ibunya bernama Muznah berasal dari Palekat Madras tetapi lahir di Surabaya Sejak tahun 1924, ${ }^{19}$ A. Hassan emperoleh sebagian besar pendidikan dari ayahnya sejak masih muda. A. Hassan tercatat antara lain menjadi guru agama dan guru bahasa yang dikuasainya, yaitu: Melayu, Inggris, Arab dan Tamil. Ia juga pernah menjadi guru di Singapura dan beberapa tempat di Malaya (Malaysia) serta di Sanglang dan Benut daerah Kutub. Di samping itu ia pernah berdagang permata, minyak wangi, dan menjadi agen distribusi es, vulkanisir ban mobil, juga menjadi kolumnis surat-surat kabar terbitan Singapura dan tanah Malaya. Dua tahun lebih pernah menjabat anggota pengarang harian berpengaruh di Malaya dan di Singapura pada "Utusan Melayu" milik Singapore Free Press ${ }^{20}$ Di harian tersebut, selain menuangkan tulisan-tulisannya yang bersifat nasihat, ia juga terampil menuangkan berbagai kritikannya terhadap masalah-masalah yang dianggapnya bertentangan dengan agama. Kala itu A.Hassan sangat gemar membaca banyak tulisan-tulisan para pembaru dalam majalah al-Manār (Kairo), al-Imām (Singapura), al-Munir (Padang), serta karya tulis Syekh Ahmad Sookarti yang beliau temukan di sebuah buku berjudul surat al-jawāb tahun 1914.

Dalam usaha pembaharuannya, A. Hassan memiliki etos juang dan metode pendekatan yang heroik, di samping sikapnya yang

\footnotetext{
${ }^{18}$ Dadan Wildan dkk, Anatomi Gerakan Dakwah...,236.

${ }^{19}$ A. Hassan, Terjemah Bulūgh al-Marm, (Bandung: CV. Diponegoro, 1982.)

${ }^{20}$ Roebaie Widjaya dalam: Hujjat al-Islām, (Bandung: Majalah Persatuan Islam, 1956 ), 35-36.
} 
heroik ia memiliki kepribadian yang supel,simpatik, dan sabar. Pendekatan yang digunakan dalam menyampaikan pikiran dan citacitanya, dengan cara debat yang cenderung menantang konflik, sehingga banyak mengundang respon dan gejolak yang cukup hangat. A.Hassan merupakan seorang pemikir Islam yang sangat menyukai diskusi. Bahkan sejarah telah mencatat bahwa Ahmad Hassan sering melakukan diskusi kritis bersama Presiden Soekarno tentang berbagai hal yang salah satunya adalah diskusi tentang konsep Negara bangsa. Berkali-kali ia melakukan diskusi, di berbagai tempat ia melakukannya, baik dengan sesama muslim maupun dengan nonmuslim. Kegiatan lain yang dilakukannya adalah dalam bidang penafsiran al Quran dalam bahasa Indonesia, yang kemudian dikenal dengan Tafsir al-Furqān. Dalam usaha penerbitannya, A. Hassan melancarkan polemik-polemik yang dapat merangsang pemikiran dan daya kritis umat yang lebih besar. Semisal Al-Lisān, media cetak berkala Persatuan Islam, menjadi corong yang menggaungkan suara Persatuan Islam dari segala penjuru yang bukan saja dalam hal pemikiran hukum Islam, tetapi juga melancarkan polemik-polemik mu'amalah, politik dan ideologi pada zamannya. Kegiatan A. Hassan ini cukup memberikan dampak positif, sekaligus menjadi model bagi kepentingan gerakan pembaruan Islam di tanah air. Bahkan Pengaruh pemikiran A. Hassan kini telah tersebar luas di Indonesia, Malaysia, Singapura dan Thailand.

Persis menyelenggarakan kelas pendidikan akidah dan ibadah bagi orang dewasa. Lembaga pendidikan itu kemudian semakin berkembang sejak Ahmad Hassan masuk dalam Persis pada tahun 1926. Perkembangan di Persis tidak hanya terjadi pada pendidikan tetapi di bidang literasi dan publikasi seperti pencetakan buku-buku dan majalah juga berkembang pesat. Namun Menjelang pendudukan Jepang di Indonesia, yaitu pada tahun 1941, A. Hassan pindah ke Bangil atas permintaan keluarganya. Di Bangil ia meneruskan perjuangan seperti apa yang telah dialaminya di Bandung, yaitu mendirikan Pesantren Persatuan Islam. A. Hassan tinggal di daerah ini berlangsung sampai akhir hayatnya. Pada tanggal 10 Nopember 1958 A. Hassan berpulang ke rahmatullah dalam usia 71 tahun $^{21}$ Karya-Karya Ahmad Hassan: Tafsir al-Qur'an al-Furqan, soal jawab tentang berbagai masalah agama, Terjamah Bulughul Marqam(1958),

${ }^{21}$ Dadan Wildan dkk, Anatomi Gerakan Dakwah...,233. 
Al-Farāid, al-Jawāhir, al-Manāsik, al-Mazhab, al-Mukhtār, alNubuwwah, al-Tauhìd.

\begin{abstract}
Abdul Qadir Hassan; Ulama Hadis dari Bangil
Buah jatuh tak jauh dari pohonnya. Demikianlah gambaran tentang sosok Abdul Qadir bin Hassan bin Ahmad, anak dari tokoh terkemuka organisai. Persatuan Islam (PERSIS), Ustadz A. Hassan. ${ }^{22}$ Mengikuti jejak sang ayah, Abdul Qadir Hassan juga dikenal sebagai salah seorang tokoh di Indonesia yang menggeluti ilmu hadis dan fikih. Ulama yang memimpin serta membesarkan Pesantren Persatuan Islam di Bangil, Jawa Timur, pasca wafatnya ayahnya A. Hassan. Ia dikenal dengan karya-karyanya yang cemerlang seperti: Buku Ilmu Musthalah Hadis, Min al-Wahyi, Qamus al-Qur'an.
\end{abstract}

K.H. Latief Muchtar (1931-1997): Dari Progresivisme hingga Ekslusivisme.

KH. Latief Muchtar, MA dilahirkan di Garut pada tanggal 7 Januari 1931, dari pasangan KH. Muchtar dan Hj. Memeh. Beliau pernah mengenyam pendidikan di Pendis yang dipimpin oleh $\mathrm{M}$. Natsir dan juga pesantren Islam Pajagalan, Bandung. Dan dikenal Sebagai orang yang dididik dan dibesarkan di lingkungan PERSIS, Latief terlibat taktif dalam organisasi PERSIS ketika masih remaja melalui organisasi Pemuda PERSIS, organisasi otonom di bawah PERSIS. Aktivitasnya dimulai sebagai anggota pemuda PERSIS ketika ia masih duduk di bangku Mualimien selain itu, tercatat pada tahun 1947/1948 pernah belajar di pesantren Dār al-Latîf di Garut, SMP Muhammadiyah Bandung (1951), Dan SMA 3 Bandung. pada tahun 1957 beliau berangkat ke Mesir, untuk mengikuti kuliah di Universitas Darul Ulum Kairo. Sepulang dari Mesir, selain aktif di Persatuan Islam, beliau menjadi dosen IAIN Sunan Gunung Djati Bandung, hingga menjabat sebagai Pembantu Rektor I IAIN SGD Bandung, di samping sebagai dosen di lingkungan Kopertais wilayah III Jawa Barat. Beliau sempat kuliah program S3 di IAIN Syarif Hidayatullah, Jakarta, namun tidak sempat menyelesaikan disertasinya karena kesibukan sebagai Ketua Umum PP. Persatuan Islam, yang dijabatnya pada tahun 1983 sejak meninggalnya KHE. Abdurrahman. Selain sebagai Ketua Umum PP. Persatuan Islam pada

\footnotetext{
${ }^{22}$ Andirsyah Hosen, Ideologi Muslim: Pencairan dan Pergulatan Persis (Jakarta: Serambi, 1923), 27.
} 
Muktamar ke-II Pemuda PERSIS 17-20 September 1953 bertepatan dengan Muktamar PERSIS ke V, Latief terpilih sebagai Ketua Umum Pimpinan Pusat Pemuda PERSIS masa jihad 1953-1956. KH. Latief Muchtar, MA., tercatat menjabat sebagai anggota pengurus ICMI Pusat, dan aktivis Dewan Dakwah Islam Indonesia (DDII) yang sering mewakili DDII di forum-forum Islam internasional, seperti di OKI, Dewan Mesjid se-Dunia dan lain sebagainya. Tugas-tugas ke forum Islam internasional tersebut, di antaranya mewakili Moh. Natsir dari Indonesia, yang dicekal oleh Pemerintah RI, sehingga tidak bisa pergi ke luar negeri. ${ }^{23}$

Selama kepemimpinan KH. Latief Muchtar, MA., Persatuan Islam tampak seperti di simpang jalan. Meskipun secara tegas KH.Latief Muctar, MA dapat menentukan pijakannya yang khas, tetapi kontinuitas organisatoris tetap merupakan prinsip kelanggengan organisasi Persatuan Islam. Namun begitu, dari perjalanan Persatuan Islam yang cukup panjang dan bervariasi itu, sejak periode A. Hassan yang cenderung progresif hingga periode KHE. Abdurrahman yang cenderung eksklusif, KH. Latief Muchtar, MA sebagai seorang cendekiawan muslim yang berbasis akademis menentukan arah organisasi yang tepat dan strategis yakni, orientasi intelektualitas bagi Persatuan Islam. Namun dalam perjalanan berikutnya, tampak pula Persatuan Islam di bawah kepemimpinannya merambah kembali bidang politik. Ia sendiri kemudian masuk menjadi anggota DPR/MPR RI. Ijtihad politiknya ini mungkin dirasakan oleh sebagian tokoh Persatuan Islam yang lain cukup mengagetkan, karena pada periode sebelumnya sepertinya bidang ini "haram" untuk disentuh dan dianggap bukan merupakan bidang garapan Persatuan Islam. Loncatan ini sesungguhnya di samping menandai masa berakhirnya masa ekslusivisme yang selama itu disandang oleh Persatuan Islam, juga mengemban misi khusus. Yakni memberikan warna tertentu bagi perkembangan politik di Indonesia. Karena bagaimana pun, Persatuan Islam (PERSIS) akan selalu berhadapan dengan kebijakan nasional di mana ormas Islam itu berdiri. Inklusif misalnya menyangkut undang-undang keormasan di Republik ini. ${ }^{24}$ di mana Pancasila diterima sebagai satu-satunya azas bagi ormas Islam, hal itu dipandang sebagai suatu kelemahan para

${ }^{23}$ Dadan Wildan dkk, Anatomi Gerakan Dakwah...,243

${ }^{24}$ H. Iman Sudarwo Padmosugondo, Lima Undang-undang Bidang Pembangunan Politik, (Surabaya: Indah, 1988), 146-155. 
politisi muslim di tanah air saat itu. Dan bagi Persatuan Islam, penerimaan ini terkesan bersikap jabari atas ketidakberdayaannya dalam menentukan alternatif lain. Karena itu, seharusnya Persatuan Islam menempatkan wakilnya dalam majelis tertinggi negara itu, agar aspirasi politiknya bisa terlihat dan tersalurkan. Karenanya eksklusivisme yang pernah dikembangkan Persatuan Islam pada periode sebelumnya, maka pada saat situasi dan kondisi politik itu berubah baik secara radikal revolusioner maupun secara gradual, dinyatakan bahwa berijtihad dan proaktif dalam menentukan sikap politik tanpa mengubah ormas Persatuan Islam menjadi partai politik atau tetap mempertahankan kemandirian jam'iyah tanpa mengekang kebebasan berpolitik bagi pribadi-pribadi warganya, hal ini menjadi suatu keharusan.

KH. Latief Muchtar, MA sendiri tercatat sebagai anggota DPR/MPR RI, untuk periode 1998-2003 dari Fraksi Persatuan Pembangunan (FPP). Namun beberapa hari sebelum dilantik sebagai anggota Dewan, beliau meninggal dunia di Jakarta dalam rangka mengikuti acara gladi bersih pelantikan tersebut, pada tanggal 12 Oktober 1997 akibat serangan penyakit jantung. ${ }^{25}$ Karya-karya K.H. Latief Muchtar diantaranya: Penulis buku "Sejarah Perjuangan Persis", Pendiri tinggi tahun 1988.

KH. Drs. Shiddiq Amien: Mengemban Amanat hingga Akhir Hayat (Mantan Ketua Umum PERSIS 1997-2009).

KH. Shiddieq Amien yang memiliki nama asli Shiddiq Aminullah, dan biasa akrab disapa oleh umat Islam Bandung dengan panggilan Ustadz Shiddiq. Lahir 13 Juni 1955 di kampung Benda kecamatan Cipedes, Tasikmalaya. Ayahnya bernama K.H Utsman Aminullah dan Ibunya bernama H.J E. Hamidah, yang mana ayahnya merupakan murid dari A. Hassan guru utama PERSIS. KH. Shiddieq Amien sebagai Ketua Umum Persatuan Islam pada tahun 1997 dan wafat 31 Oktober 2009. Ustadz Shiddieq memimpin PP. Persatuan Islam menggantikan ketua umum yang lama, KHA. Latief Muchtar, MA karena wafat pada tahun 1997. Menurut teman-teman sejawatnya di Muallimien lulusan tahun 1975, Pesantren Persatuan Islam Pajagalan No. 1 Bandung, Ustadz Shiddieq muda dikenal sebagai kutu buku dan penceramah agama yang intens. Setelah sarjana bahasa inggris yang diraihnya di Akademi Bahasa Asing di

${ }^{25}$ Dadan Wildan dkk, Anatomi Gerakan Dakwah...,245 
Bandung, ternyata beliau lebih memilih dunia pesantren ketimbang modal kesarjanaan bahasa yang dimilikinya untuk melanglang buana, maksudnya adalah mengembara keliling dunia dengan ilmu pesantren yang dimilikinya. Serta Beliau lebih memilih membesarkan Pesantren Persatuan Islam Cabang Benda Tasikmalaya, tempat beliau lahir dan dibesarkan. Karena pesantren tersebut sesungguhnya merupakan tempat pewarisan ilmu dari ayahnya, KH. Amienullah. Dengan wawasan pengetahuan Islamnya yang sangat luas KH. Shiddieq Amien sering melakukan ceramah.

Beliau adalah seorang intelektual dan ulama ternama dalam jajaran jamiyyah Persatuan Islam. Sebagai ulama ia mampu membawa jamiyyah PERSIS ke level mengagumkan. Dan sebagai seorang intelektual muda, ia mampu menyatukan tradisi keulamaan dan keintelektualan secara sinergis, dengan harmonisasi yang cukup terintegritas dalam satu wawasan berfikir yang matang. ${ }^{26}$ Persatuan Islam selama di bawah kepemimpinan KH. Shiddieq Amien, mungkin tidak seprogresif ketika di dipimpin KH. Latief Muchtar yang akademisi dan lincah, tetapi beliau lebih menitikberatkan pada kemajuan pesantren, yang pada umumnya di lingkungan Persatuan Islam, pesantren-pesantren itu dikelola oleh cabang Persis di daerah masing-masing. Dengan mengunjungi cabang-cabang dan menyampaikan ceramah, adalah cara beliau dalam menumbuhkan gairah berorganisasi dan memajukan pesantren terlihat keberhasil begitu berhasil. Moralitas yang ditanamkan Ustadz Shiddieq melalui kunjungan-kunjungan ke daerah sangat berarti dan sangat besar pengaruhnya bagi jamaah Persatuan Islam yang berada di daerah. pesantren-persantren yang dikelola oleh cabang-cabang Persatuan Islam di daerah muncul ke permukaan dan banyak diminati santrisantri dari berbagai daerah lain, justru pada saat Persatuan Islam dipimpin oleh Ustadz Shiddieq. Pesantren Persatuan Islam Cabang Benda Tasikmalaya, jauh lebih maju dan diminati ribuan santri. Begitu pula pesantren Persatuan Islam di Garut, jauh lebih pesat dibandingkan sepuluh tahun sebelumnya. ${ }^{27}$ Gairah masyarakat menggali al-Qur'an dan as-Sunnah sebagai sumber ajaran Islam mendapat animo yang besar di lingkungan Persatuan Islam ketika Shiddieq Amien memimpin ormas ini. Hal ini berbanding lurus ketika di zaman KH. Latief Muchtar memimpin Persis, di mana

\footnotetext{
${ }^{26}$ Andirsyah Hosen, Ideologi Muslim: Pencairan dan Pergulatan Persis..., 28.

${ }^{27}$ Dadan Wildan dkk, Anatomi Gerakan Dakwah ...,249
} 
dunia politik Islam khususnya di lingkungan Persatuan Islam sangat bergairah, bahkan setiap orang ingin menjadi syuhada untuk mengubah keadaan yang lebih baik dan Islami sesuai dengan kaidahkaidah dan fasilitas kemodernan. Dapat diakui Shiddiq Amien adalah penerus tokoh PERSIS yang mampu melanjutkan peralihan dari tradisi lama menjadi tradisi baru, dari wajah PERSIS yang eksklusif dan tertutup menjadi terbuka, adaptif, toleran terhadap segala permasalahan ia mampu menjadi pemahaman antara kalangan santri dan kaum akademis. Selama kariernya sebagai ulama, KH. Shiddiq Amien telah menulis beberapa buku Islam, diantaranya: Presiden Wanita dalam Pandangan Islam (2001), Islam; dari Aqidah hingga Peradaban (2010), Keluarga Berencana dalam Pandangan Islam (2001).

K.H.E Abdurrahman (1912-1983): Politik Ulama

Cikal bakal Ulama Besar dan Guru Besar, serta Pimpinan Persatuan Islam ini, lahir di kota Cianjur, pada tanggal 12 Juni 1912, ayahnya bernama Ghazali, sedang ibunya bernama Hafsah, dengan jumlah saudara 13 orang, beliau merupakan putra yang paling cikal dari yang ada. Setelah khatam al-Qur'an pada usia 7 tahun, pendidikan beliau dilanjutkan dengan pendidikan di madrasah NU al-I'ānah Cianjur. Setelah usai meraih pendidikan di al-I'ānah, atas permintaan keluarga besar SWARHA Bandung, beliau dipanggil untuk mengajar di madrasah Nahdlatul Ulama al-I'ānah Bandung. ${ }^{28}$

Pada tahun 1934, bergabung dengan M. Natsir dalam Pendis (Pendidikan Islam) di jalan Lengkong Besar Bandung. Bersama itu pula beliau mulai tertarik dengan pemikiran keagamaan A. Hassan, guru Persatuan Islam, bahkan beliau akhirnya menjadi murid A. Hassan yang paling akrab. Beliaulah yang paling setia mendampingi gurunya dalam berbagai kegiatan, beliau pula yang dengan setia mendampingi A. Hassan ketika sakit di Mekkah al-Mukaramah, dalam rangka menjalankan ibadah haji. KHE. Abdurrahman merupakan guru besar kedua setelah A. Hassan. Ini merupakan penilaian para tokoh Persatuan Islam dan Cendekiawan Muslim Bandung. dikarenakan pandangan-pandangan keagamaan dalam Persatuan Islam lebih banyak diwarnai oleh kedua tokoh tersebut. Walaupun tidak bisa dikesampingkan peran dari tokoh-tokoh lainnya. Namun, khususnya di bidang fiqh, hanya kedua tokoh inilah

${ }^{28}$ Ibid.,239 
yang paling menonjol di antara para tokoh Persatuan Islam lainnya. Pada tahun 1957, turut terlibat dalam arena politik, menjadi anggota Konstituante Republik Indonesia dari Fraksi Masyumi, dengan nomor anggota 246, hingga akhirnya Konstituante dibubarkan oleh rezim Soekarno. Tahun 1959, diangkat menjadi dosen Universitas Islam Bandung. Tahun 1967, diangkat menjadi dosen FKIT-IKIP Bandung, untuk mata kuliah Pendidikan Agama Islam. Tahun 1968, dalam Muktamar Persatuan Islam di Bandung, beliau diangkat menjadi Ketua Umum Persatuan Islam, berturut-turut selama tiga kali pengangkatan, jabatan yang didapat setelah kepemimpinan KHM. Isa Anshary. Bila pada kepemimpinan K.H Isa Ashary, Persis kental dan akrap dengan politik prakris, namun berbeda ketika berada di bawah kepimpinan K.H.E Abdurrahman yang sepertnya acuh tak acuh akan politik. ${ }^{29}$

Selama masa kepemimpinannya dari tahun 1963-1983, Persis lebih cenderung terhadap kegiatan-kegiatan sekitar tablig dan pendidikan, sedari tingkat pusat hingga ketingkat cabang. Hal inipun tidak terlepas dari kebijakan, langkah dan perhatian K.H.E Abdurrahman. ${ }^{30}$ Dan ia merorientasikan Persis sebagai "organisasi agama". Sebab ia mengambil pola kepemimpinan ulama, bukan political leader. Dan kembali kepada garis perjuangannya, sehingga tidak salah apabila Dadan Wildan mengatakan bahwa K.H.E Abdurrahman sebagai penegak Khittah Persis. ${ }^{31}$ Serta juga merorientasi kembali menjadi organisasi yang memusatkan perhatian dibidang sosial keagamaan.

Pada usia 71 tahun, K.H.E. Abdurrahman menderita sakit yang cukup serius, dan hampir tiga kali menjalani opname di RS. Hasan Sadikin. Hingga pada akhirnya Allah SWT memanggil beliau, tepatnya pada hari Kamis, 21 April 1983, jam 02.30 WIB di RS. Hasan Sadikin Bandung. Umat Islam telah kehilangan sosok ulama besar seperti beliau, yang mana dalam penuturan Bapak M. Natsir: "Sepanjang pergaulan saya di Rabithah 'alam Islamy, saya belum menjumpai ulama yang akurat seta cermat dalam dalam Ilmu Hadis

\footnotetext{
29 Persis Dalam Presfiktif Sejarahnya, "Majalah" (Risalah No.13/XXVIII, Mei 1990), 18

${ }^{30}$ Dadan Wildan Annas, K.H.E Abdurrahman dan sejarah Pembaharuan Islam di Indonesia, "Majalah" (Risalah No.6 TH XXXV, Agustus 1997), 20

${ }^{31}$ Wildan, Dadan, Yang Dai Yang Politikus: Hayat dan Perjuangan Lima Tokoh Persis..., 135
} 
seperti Ustadz K.H.E Abdurrahman”. Dinyatakannya sebagai tokoh islam kaliber internasioanal ini, memang bukanlah sekedar basa-basi memuji almarhum, melainkan suatu pernyataan lugas yang didukung pula oleh tokoh Islam seperti DR. KH. EZ. Mutaqin: "Beliau adalah ulama yang paling dalam di bidang Hadis dan Tafsir". Dan ketika KHE. Abdurrahman wafat, majalah Risalah yang telah dipimpinnya, menurunkan tulisan berupa cuplikan tulisan yang telah dimuat di berbagai Harian di Bandung.

Karakteristik tokoh ini tampak eksklusif, anggun dan sangat berwibawa. Demikian sehingga banyak orang yang menganggap bahwa Persatuan Islam di bawah kepemimpinannya tampak tertutup. Progresivisme Persatuan Islam yang muncul sebelumnya, di bawah KHE. Abdurrahman, nyaris tidak lagi tampak. Gagasan dan gerakan dalam percaturan politik pun tidak lagi terasa sengatannya. Padahal sebelumnya, ia sesungguhnya pernah menjadi anggota parlemen di masa Soekarno. Persatuan Islam di bawah kepemimpinannya, mencapai kemajuan pesat. Dengan kemampuannya dalam bidang Fiqh, Tafsir dan Hadits, KHE. Abdurrahman membina Persatuan Islam dan umat pada umumnya melalui sektor pendidikan dan dakwah. Dengan kata lain, K.H.E. Abdurrahman sangat memperhatikan pendidikan sebagai salah satu lembaga strategis bagi pengkaderan Persatuan Islam. ${ }^{32}$

K.H.E. Abdurrahman merupakan seorang penulis produktif, tulisan lepasnya banyak tersebar di majalah-majalah. Materi-materi khutbah Jumat, khutbah Idul Fitri dan Idul Adha disusunnya dengan baik. Buku-buku yang pernah dtulisnya antara lain jihad dan Qital, Darul Islam, Ahlus Sunnah wal jamaah, Dirasah Ilmu Hadits, Perbandingan Mazhab, Ahkamusyar'i; Risalah Jum'at, Recik-Recik Dakwah, Sekitar Masalah Tarawih, Takbir, dan Shalat Ied dilengkapi khutbah Iedul Fitri, Hukum Qurban, Aqiqah, dan Sembelihan, Petunjuk Praktis Ibadah Haji, Renungan Tarikh; Mernahkeun Hukum Dina Agama, Syiatu aly, dan Risalah Wanita. Selain itu, ia juga menuliskan pemirannya dalam bentuk tanya jawab pada majalah Risalah dalam ruang "Istifta". 33

\footnotetext{
32 Asep S. Muhtadi, makalah: "Kyai dan Politik Pembaharuan: Kasus Persatuan Islam," tidak dipublikasikan, ( Semarang, 1408 ) 11.

${ }^{33}$ Wildan, Dadan, Yang Dai Yang Politikus: Hayat dan Perjuangan Lima Tokoh Persis...,123
} 


\section{Epilog}

Persatuan Islam (PERSIS) berdiri pada permulaan tahun 1920-an. Tepatnya tanggal 12 september 1923 di bandung. Persis berawal dari suatu kelompok diskusi atau tadarusan (penelaahan agama Islam) di kota Bandung di bawah pimpinan H. Muhammad Zamzam dan H. Muhammad Yunus. Bersama para jama'ahnya dengan penuh kecintaan menelaah, mengkaji serta menguji ajaranajaran Islam. sejak saat itu, timbullah gagasan di kalangan mereka untuk medirikan organisasi Persatuan Islam atau nama lain yang diajukan oleh kelompok ini, yaitu Permupakatan Islam. begitupun karakteristik kajian hadis dalam ormas Persis atau bisa dibilang cara dakwah dalam penyebaran islam yakni dengan mengadakan pertemuan-pertemuan umum, tabligh, khutbah, kelompok studi, tadarus, pendirian sekolah-sekolah (pesantren), penerbitan majalahmajalah dan kitab-kitab. Melalui penerbitan inilah Persatuan islam (PERSIS) menyebarluaskan pemikiran dan ide-ide mengenai dakwah dan tajdid. Gerakan dakwah dan tajdid Persis juga dilakukan melalui serangkaian kegiatan khutbah dan tabligh yang kerap digelar di daerah-daerah, baik atas inisiatif Pimpinan Pusat Persis, permintaan dari cabang-cabang, undangan dari organisasi Islam lainnya, maupun atas permintaan masyarakat luas. berbagai aktivitas keagamaan lainnya, Dalam bidang pendidikan, diselenggarakan kelas pendidikan akidah dan ibadah bagi orang dewasa. begitu pula kontribusi dari ormas ini diantaranya didirikannya lembaga pendidikan kanak-kanak dan Holland Inlandesch School (HIS) yang merupakan proyek lembaga Pendidikan Islam (Pendis), serta banyaknya kitab-kitab mengenai keilmuan maupun kajian hadis yang diterbitkan oleh ormas ini. Tokoh-tokoh dalam ormas persis yang juga banyak menghasilkan karya-karya terkait dalam bidang kajian Hadis dan terkait persoalan hukum dalam islam diantaranya :Muhammad Isa Anshary, Mohammad Natsir, Ahmad Hasan, Abdul Qadir Hassan, K.H. Latief Muchtar, Drs. Shiddiq Amien, K.H.E Abdurrahman.

\section{Daftar Pustaka}

Ali. Fachry dan Bachtiar Effendi, Merambah Jalan Baru Islam: Rekonstruksi Pemikiran IslamIndonesia Masa Orde Baru, Bandung: Mizan, 1986.

Annas. Dadan Wildan, Badri, Taufik, Anatomi Gerakan Dakwah , Bandung:2010. 
Annas. Dadan Wildan, Sejarah Perjuangan Persis 1923-1983, Bandung: Gema Syahida, 1995.

--------. Yang Dai Yang Politikus: Hayat dan Perjuangan Lima Tokoh Persis, (Bandung: Rosda, 1997).

Anshary . M. Isa, Mujahid Da'wah, Bandung: CV. Diponegoro, 1984.

Bakar. Abu, Sejarah Hidup KHA. Wahid Hasjim dan Karangan Tersiar, Jakarta: Panitia buku peringatan alm. KHA. Wahid Hasjim, 1957.

Deliar Noer, Partai di Pentas Nasional 1945-1965, Jakarta: Pustaka Utama Grafiti, 1987.

------- . Gerakan Modern Islam di Indonesia 1900-1945, Jakarta: LP3ES, 1945.

Hassan A, Terjemah Bulūgh al-Marm, Bandung: CV. Diponegoro, 1982.

Hosen. Andirsyah, Ideologi Muslim: Pencairan dan Pergulatan Persis ,Jakarta: Serambi, 1923.

Howard. Federspiel, Persatuan Islam, Islamic Reform in Twentieth Century Indonesia, NewYork: Modern Indonesia Project Southeast Asia Program, Cornell University, 1970.

Khaeruman. Badri, "Mengenang Jasa M. Natsir", Dalam Suara Kampus IAIN SGD, Bandung: edisi XV, 23 Pebruari 1993.

L. Stoddar, Dunia Baru Islam, Jakarta: Panitia Penerbit, 1996.

Malik. Dedy Djamaluddin, "Persis Terdesak Akhirnya Defensif", Artikel dalam Pikiran Rakyat,Bandung, 1990.

Muchtar . A.Latief, Gerakan Kembali ke Islam, Bandung: Rosda, 1998.

Muhtadi. Asep S, makalah: "Kyai dan Politik Pembaharuan: Kasus Persatuan Islam," tidak dipublikasikan, Semarang, 1408 .

Padmosugondo . H. Iman Sudarwo, Lima Undang-undang Bidang Pembangunan Politik, Surabaya: Indah, 1988.

Qanun Asasi, Persatuan Islam ,Yogyakarta: PT Bentang Pustaka, 2010.

Qanun Asasi dan Qanun Dahili Persatuan Islam, Bandung: PP. Persis, 1968.

Rohman.Taufiq dan Beni, “Membangun Gerakan Inklusivisme Model Jamaah Persatuan Islam"jurnal Temali: jurnal pembangunan Sosial vol 1 no1,19 Januari 2020.

Rosidi. Ajip, M. Natsir, Sebuah Biografi, Jakarta: Giri Mukri Pasaka, 1990. 
Wahid . Abdul, Ramli, Perkembangan Kajian Hadis di Indonesia, Study Tokoh dan OrmasIslam, Makalah Postgraduate Programs IAIN and UIN, Makasar: 25-27 November, 2005.

Widjaya. Roebaie, dalam: Hujjat al-Islām, Bandung: Majalah Persatuan Islam, 1956. 